\title{
Mid-Tertiary Stratigraphy of the Continental Slope off Nova Scotia*
}

\author{
GRANT A. BARTLETT \\ Atlantic Oceanographic Laboratory, Bedford Institute, Dartmouth, N. S.
}

\section{Introduction}

Planktonic Foraminifera of Oligocene-Miocene age have been obtained from dredge hauls and cores in submarine canyons and ledges that occur along the continental slope off Nova Scotia (Fig. 1). The stratigraphic section with its mid-Tertiary microfauna was first reported by Bartlett (1967). Bartlett (1968) also discussed some of the characteristic species of planktonic Foraminifera in detail. To date, samples of consolidated Tertiary sediment containing planktonic Foraminifera have been collected in depths as great as 2200 metres along the continental slope.

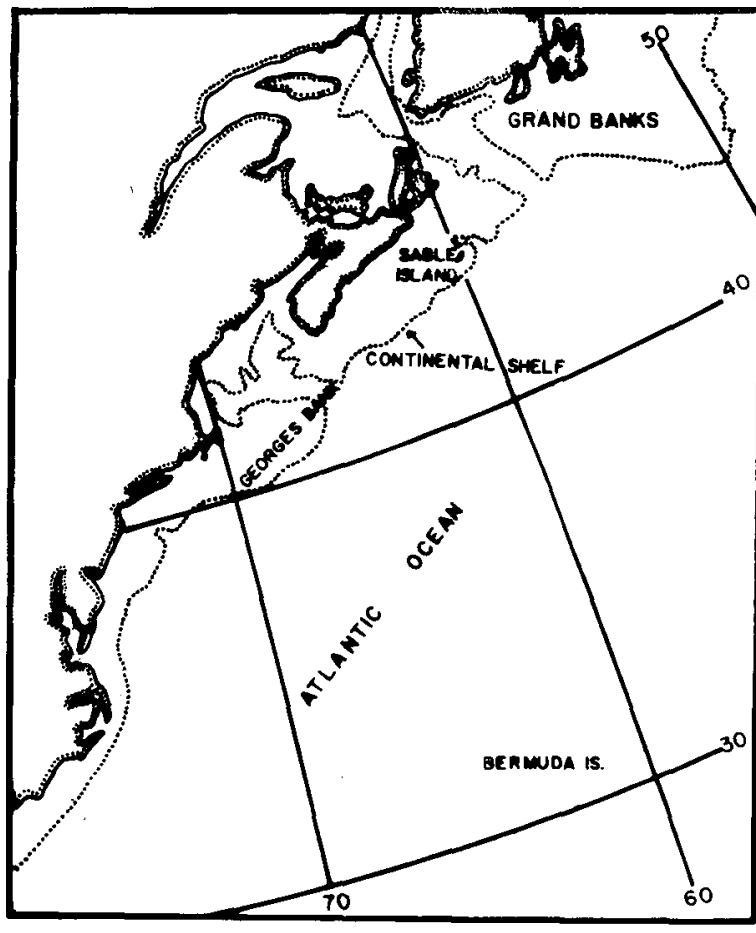
Fig. I Location map of Study area. Dotted line indicates outer limit of continental shelf with depth of approximately 187 metres.

Sparker profiles along the sides of the Slope show that persistent, gently-dipping reflecting horizons are present in the subsurface. Continuous reflectors are present at 450, 550, and 650 metres below sea level. Discontinuous reflectors occur in various canyons at lesser depths and appear to represent sturctures within poorly-consolidated or unconsolidated deposits of probable Pleistocene age. Sparker surveys have thus far been unsuccessful in depths greater than 500-600 metres, probably because of the steepness and ruggedness of the canyons below that depth range. The present sparker information, however, suggests that the shelf and sides of the slope are underlain by rock formations which have acoustical discontinuities at vertical spacings comparable to the spacings of topographic ledges and at similar elevations.

The stratigraphic section examined to date extends from the Globigerina opima opima zone to at least the top of the Globorotalia mayeri zone. The major portion of the section extends from the Catapsydrax dissimilis zone through the Globorotalia fohsi sensu lato zone. Eocene and Cretaceous sediments have also been collected as erratics in a few dredge hauls. Particular boundaries cannot be established because of the nature of the samples. Both planktonic and benthonic assemblages are comparable to those described from Trinidad and Venezuela, in particular, and the Caribbean area in general. The similarity of these assemblages with those in the Caribbean area suggests the presence of a proto-Gulf Stream and a warm climatic belt extending from the Caribbean to at least southern Newfoundland (North latitude $46^{\circ} 00^{\prime}$ ) during Oligocene-Miocene time.

*Manuscript received June 4, 1968; Bedford Institute Contribution No. 124. 



\section{Previous Work}

The first of a series of investigations concerning the geological structure of the continental slope was carried out in 1964 by the Geological Survey of Canada and the Bedford Institute. Subsequent investigations by J. I. Marlowe in 1965 and 1966 were centered on the Gully, a large submarine canyon on the continental slope off Nova Scotia. The writer joined Marlowe in 1966 on "CSS HUDSON" and obtained sediment samples which were determined to be of mid to late Tertiary age on the basis of the constituent fauna. Extensive investigations in the general slope area were also conducted by the writer in 1967.

\section{Foraminifera}

\section{Benthonics}

The mid-Tertiary fauna is composed of diverse benthonic assemblages having pre dominantly calcareous-hyaline tests. Arenaceous forms are subordinate. The benthonic assemblage consists of 36 genera and 94 species representing the Lenticulina wallacei, Siphogenerina transversa and Marginulinopis basispinosis zones.

The benthonic fauna is comparable to those described from the Agua Salada GroupVenezuela (Renz 1948), the Ecphora, Yoldia and Arca facies of the Choctawhatchee Stage, Florida Panhandle (Puri 1953), the Mio-Oligocene from the Goajira Peninsula, Colombia (Becker \& Dusenbury, 1958) the Miocene Foraminifera of the Coastal Plain of the Eastern United States (Cushman \& Cahill 1932) and those reported from "The Gully" (Bartlett 1967).

Most samples containing rich benthonic foraminiferal assemblages have diagnostic Miocene Ostracodes. Samples with scattered planktonic and sparse arenaceous benthonic assemblages are characterized by abundant radiolarians and diatoms. These samples also contain abundant fibrous material, and, consequently recognition of minute foraminiferal tests is difficult.

\section{$\underline{\text { Planktonics }}$}

The planktonic population is composed of seven genera and 28 species. Globigerinoides trilobus (s.1.), Globigerinoides bisphericus, Globoquadrina dehiscens dehiscens, Globoquadrina venezuelana, Globorotalia fohsi praefohsi , Globorotalia fohsi peripheroronda, Globorotalia fohsi fohsi, Globorotalia menardii praemenardii and Globigerinatella insueta are dominant planktonic forms (Plates $\overline{1,2,3)}$. Well defined foraminiferal zones per se cannot be established along the continental slope at present (see Fig. 2). However, precise knowledge of the vertical position of particular samples and the constituent fauna permits a tentative relationship of Scotian Slope faunas with world wide zones. The planktonic fauna best represents the Globigerina ciperoensis ciperoensis - Globorotalia mayeri zones as described by Bolli $(1957,1967)$. The assemblages are comparable to, and within the Globigerinatella insueta - Globigerinoides trilobus trilobus to the Globorotalia mayeri zones in Venezuela (Blow 1959), and the assemblages described from Brazil (Closs 1967). It is obvious that the planktonic faunas have close affinities to those described from the West Indian region. Their recent counterparts inhabit these waters at the present time.

Comparable assemblages have also been described from Australia (Jenkins 1960), Honshu, Japan (Saito 1963), Mediterranean (Drooger 1960), East Africa (Eames et al 1962), Aquitaine (Jenkins 1966), British Solomons (McTavish 1966) and Egypt (Said and E1-Heiny 1967). The Scotian Shelf and Slope Tertiary faunas correspond to the Globigerina woodi to the Globigerina menardii miotumida zone in Australia, the Globigerinita unicava to within the Globorotalia bykovae zones in Japan, and the Globorotalia kugleri to the top of the Globoquadrina altispira zone as defined in the British Solomons. The Globorotalia kugleri - Globoquadrina altispira globosa to the Globorotalia fohsi fohsi zones in Egypt are probably comparable to our present

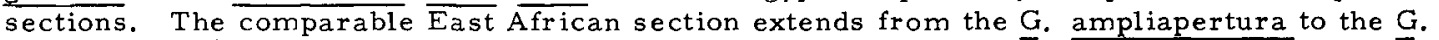
cultrata s.s./G. nepenthes zone.

\section{Faunal Succession}

The faunal succession is determined with difficulty because of the nature of the samples. Materials examined were obtained from dredge hauls and short sections in cores. First appearances, maximum abundances and faunal extinctions cannot be determined from the present 

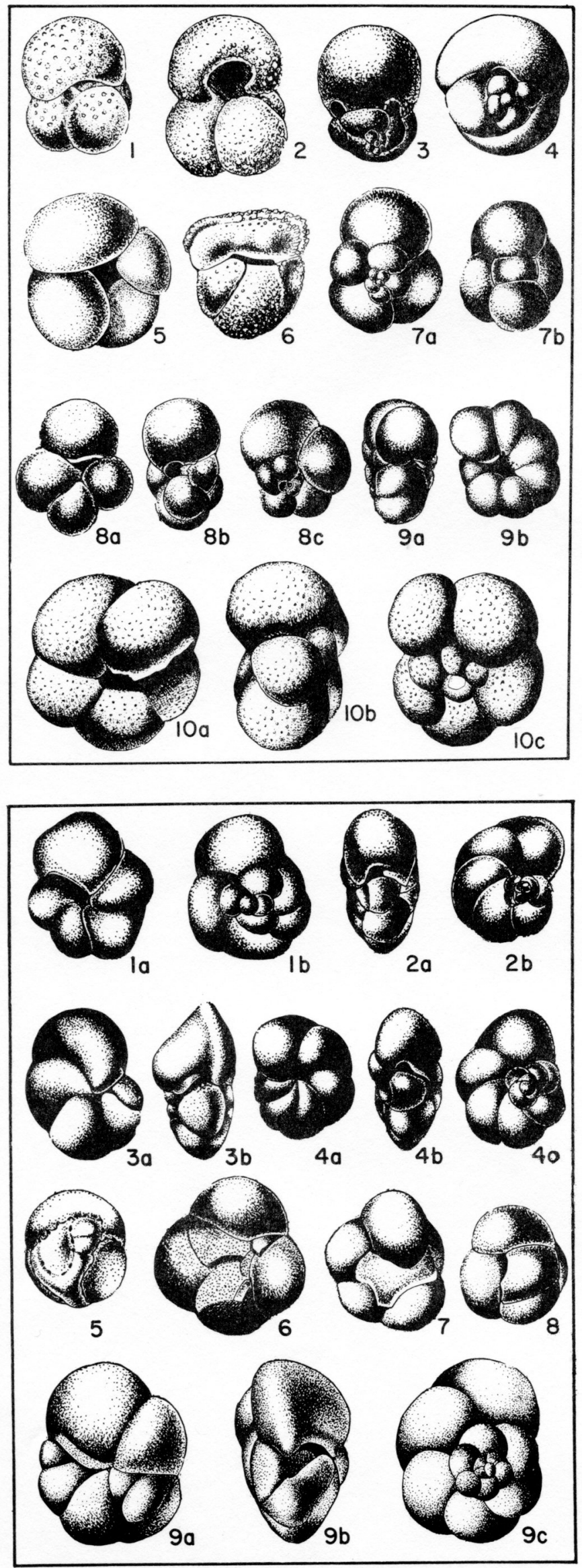

\section{PLATE 1}

1. Globigerinoides Trilobus immaturus LeRoy, umbilical view, $\times 100$.

2. Globigerinoides Trilobus altiaperturus Bolli, umbilical view, X100.

3. Globigerinoides trilobus trilobus (Reuss), spiral view,

4. Globigerinoides bispherious Todd, spiral view, $X 75$.

5. Globoguadring venezuelana (Hedberg), ventral view, $X 75$.

6. Globoquadrina dehiscens dehiscens (Chapman, Parr, Collins) ventral view X75.

7a,b. Cotapsydrax dissimilis (Cushman \& Bermudez), 7a spiral view, 76 ventral view, $\times 100$.

$8 a, b, c$. Globigerina ciperoensis angustiumbilicatula Bolli, $8 a$ ventral view, $8 \mathrm{~b}$ apertural view, $8 c$ spiral view, $X 200$.

9o,b. Globorotalia kugleri Bolli, 9a apertural view, $9 b$ ventral view, X150.

10a,b,c. Globorotalig opima opimg Bolli, 10a ventral view, $10 \mathrm{~b}$ apertural view, $10 \mathrm{c}$ dorsal view; $X 100$.

PLATE 2

1a,b. Globorotalia fohsi praefohsi Blow and Banner,

2a,b. la ventral view, $1 b$ dorsal view, 2a axial-apertural $2 b$ dorsal view, $x 100$.

3a,b. Globorotalia fohsi fohsi Cushman and Ellisor 3a ventral view, $3 \mathrm{~b}$ axial-apertural, X100.

$4 a, b, c$. Globorotalia fohsi peripheroronda Blow and Banner, 4a ventral view, $4 \mathrm{~b}$ axial-apertural, 4c dorsal view, $\mathrm{X} 100$.

5. Globigerinatella insueto Cushman and Stainforth, 5 ventral view, X100.

6. Globigerinita naparimaensis Bronnimann, 6 ventral view $\mathrm{X} 200$.

7. Catapsydrax stainforthi Bolli, Loeblich and Tappan, 7 ventral view, $X 150$.

8. Catapsydrax dissimilis (Cushman and Bermudez) ventral view, $\times 100$

$9 a, b, c$, Globorotalia fohsi peripheroronda Blow and Banner, 9a ventral view, 9b apertural view, 9c dorsal view, $X 150$. 


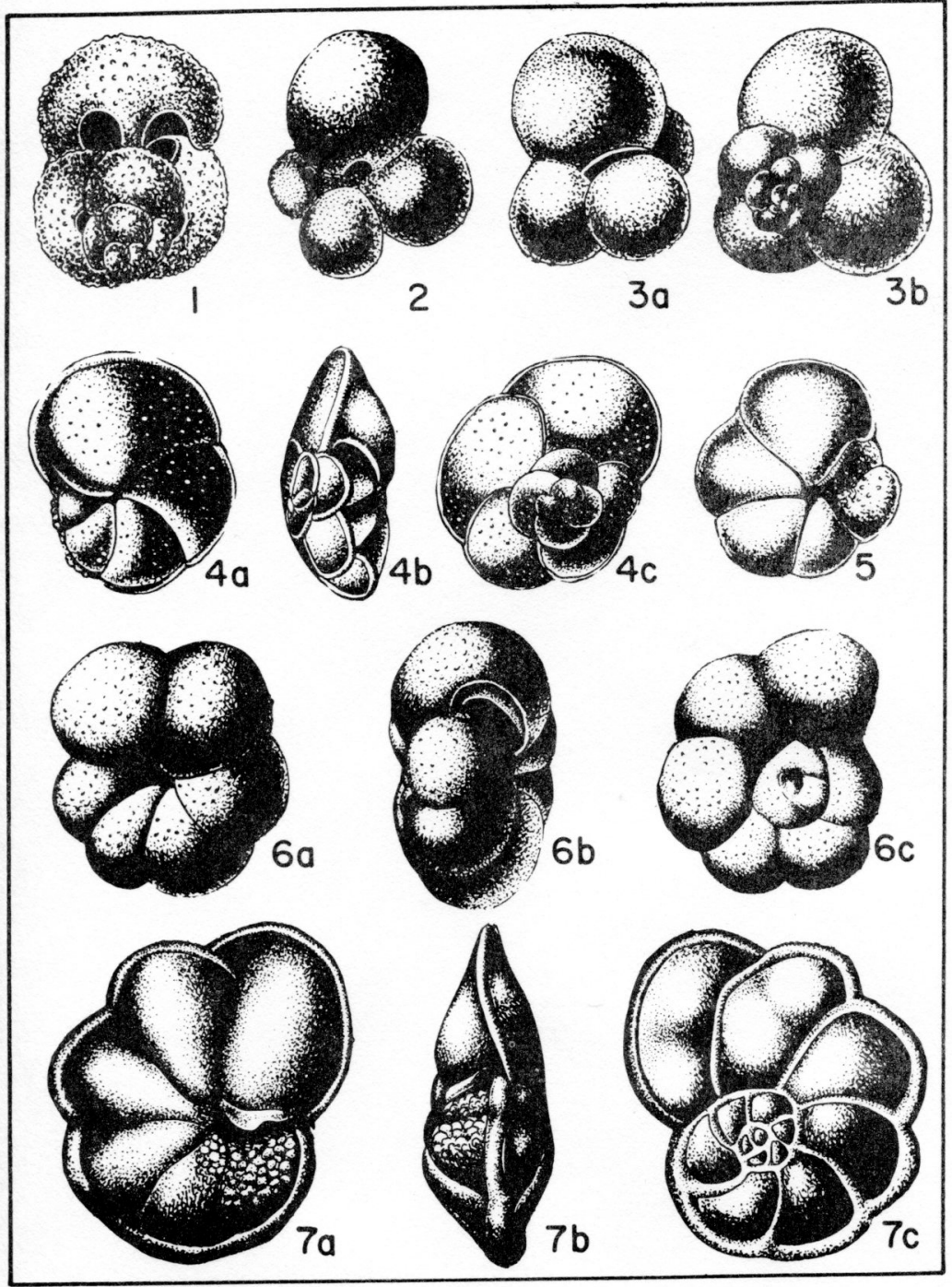

PLATE 3

1. Glabigerinoides ruber (d'Orbigny) 1. spiral view, $\times 100$.

2. Globigerina foliata Bolli, 2 ventral view $\mathrm{X} 100$.

3a,b. Globigerina juvenilis Bolli, $3 a$ ventral view, 36 dorsal view, $X 300$.

$4 a, b, c$. Globorotalia archeomenardii Bolli, $4 a$ ventral view, $4 b$ axial-apertural view, $4 c$ dorsol view, $\times 100$.

5. Globorotalia menardii proemendardii Cushman and Stainforth, 5 ventral view, X75.

6a,b,c. Globorotalia mayeri Cushman and Ellisor, $6 a$ ventral view, $6 b$ axial-apertural view, $6 \mathrm{c}$ dorsal view, $\times 100$.

7a,b,c. Globorotalia fohsi lobata Bermudez, $7 \mathrm{a}$ ventral view, $7 \mathrm{~b}$ axial-apertural view, $7 c$ dorsal view, $\times 100$.

collections. However, sufficient material permits at least partial correlation with well established sections (Fig. 2) such as those described from Trinidad and Venezuela by Bolli (1957), Blow (1959), and Blow and Banner (1966) and with East Africa, (Eames et al 1962).

If one follows Bolli (1957), Eames et al (1962), Berggren (1963), Hofker (1963) and Jenkins (1966), the presence of Globigerina ciperoensis angustiumbilicatula in the slope sediments is indicative of rocks of Oligocene age. Placing the Oligocene-Miocene boundary between the G. opima opima and $G$. ciperoensis ciperoensis or the Globorotalia kugleri - Catapsydrax dissimilis zones is beyond the scope of the present investigation. Forms resembling G. opima opima and G. ciperoensis ciperoensis have been collected from the same sample.

The appearance of typical specimens of Globigerinoides trilobus altiaperturus with Globorotalia fohsi peripheroronda is indicative of a Lower Burdigalion age. Jenkins (1966) tentatively places the Aquitainian-Burdigalian boundary between the Globorotalia kugleri and Catapsydrax dissimilis zones as defined by Bolli (1967). The association of Globigerinatella insueta and Siphogenerina transversa in the present collections denotes the upper portion of the G. insueta zone. Globigerinoides trilobus (s.1.) and G. bisphericus are dominant forms in the lower part of this zone. Similarly, the as sociation of Globorotalia menardii miotumida, Marginulinopsis basispinosis, and Globorotalia mayeri denotes the upper part of the Globorotalia mayerizone. Therefore, planktonic assemblages and planktonic - benthonic associations suggest the presence of sediments along the continental slope of at least Chattian to Tortonian age. Recent seismic and core data suggests that a Tertiary-Mesozoic section of 12,000' $-15,000^{\prime}$ underlies the entire Scotian Shelf, Slope and the Grand Banks area. This material is presently under investigation. 
Orbulina universa has not been identified in the present assemblages. This implies that sediments containing this species have not been collected, or that they appeared later (Tortonian) in our region. The presence of Porticulasphera glomerosa glomerosa and well developed Globorotalia fohsi peripheroronoda through Globorotalia fohsi (s.1.) suggests that Orbulina universa is stratigraphically above the horizons collected to date. Furthermore, the dominance of Globigerinoides trilobus (s.l.) and Globigerinoides bisphericus forms in the present collections also indicates [Blow (1956, 1959), Bolli (1957), Findlay (1947), Hornibrook (1958), Jenkins (1958, 1960)] that Orbulina universa lies above this rapidly evolving series.

\section{$\underline{\text { Paleoecology }}$}

The interpretation of depositional environments for the Tertiary off Nova Scotia is based on comparisons with the distribution of Recent assemblages of Foraminifera and encompassing sediment characteristics. Many of the species are still living in the warmer parts of the Atlantic or in West Indian waters. Comparable as semblages are not living in Recent Scotian Shelf-Slope waters.

Consolidated sediments thus far sampled from the Scotian Shelf and Slope consist of siltstone and claystone with minor occurrences of glauconitic and quartzose sandstone. The OligoceneMiocene section as presented here appears to be composed predominantly of firm, compact clay and siltstone with well-defined, laminar bedding structures. Mica, chlorite and fibrous fragments, plant remains, with concentrated spore and pollen grains are abundant in most samples. The sediment is gray to brown in color and some samples give off an odor of hydrocarbons when disaggregated. Delicate shards of brown glass occur abundantly in the upper part of the section. This zone of shards may later prove to be of considerable significance in the interpretation of regional geological history. Mineral assemblages are immature and do not have the compositional aspect of later glacio-fluvial sediment common in the shelf at the present time.

The benthonic foraminiferal assemblage is composed essentially of forms belonging to the Nodosariidae, Bolivinitidae, Buliminidae, Cibicididae and Rotaliidae. These forms indicate deposition in the Outer Shelf - Upper Slope zones of Phleger (1939-1942) or depths of 200-500 metres (Phleger 1960). The presence of Quinqueloculina and Ammonia suggests that these forms were transported from shallower nearshore depths. The faunal composition is characteristic of Continental Shelf deposition.

It is apparent that most of our present collections lie within the typical Lenticulina wallacei and Siphogenerina transversa benthonic zones as described by Renz (1948). The sediments were laid down in a typically marine open sea environment at medium depths along the Continental Shelf, probably off a warm temperate to sub-tropical coast. There are indications that the fauna was accumulated in depths of 500 to 600 metres. Tertiary sediments landward from the Slope contain predominantly inner-neritic macro and micro faunas in association with prolific spore and pollen assemblages.

The absence or scarcity of calcareous Foraminifera and the presence of deep water (> 600 metres) arenaceous forms in association with prolific radiolarian and diatom assemblages indicate deposition of the constituent sediments at great depths. These sediments are difficult to correlate but occur below the Lenticulina wallacei zone. Globigerina ciperoensis angustiumbilicatula is extremely rare in these sediments.

The presence of Globigerinoides trilobus (s.1.), G. ruber, Globorotalia fohsi (s. 1.), Globorotalia fohsi peripheroronda, Catapsydrax dissimilis and G. menardii praemenardii in Scotian Slope sediments is indicative of waters with West Indian characteristics. This situation requires a proto-Gulf Stream or a continuous West Indian connection off Nova Scotia during at least part of the Tertiary. The similarity of both planktonic and benthonic assemblages with those in Trinidad, Venezuela, Colombia, and the Florida Panhandle favours a direct connection. It is plausible that relatively uniform climatic conditions extended from the Caribbean to the Newfoundland Banks $\left(46^{\circ} 00^{\prime} \mathrm{N}\right)$ during mid-Tertiary time.

Cool-temperate to boreal planktonics (various species of Globigerina) are subordinate or absent in early and mid-Tertiary sediments but become more prolific and finally dominate through much of the late Tertiary and Pleistocene. Specimens of Globorotalia are dominantly right coiling on the Scotian Shelf and Slope in Miocene sediments and thus support a warmer- 
water hypothesis. Consequently, our study indicates that the planktonic faunal boundary, the Globorotalia line (Bandy 1960, 1964, 1966) separating diverse planktonic globorotalids and globigerinids on the south from less diverse globigerinlds on the north must be extended to at least $46^{\circ} 00^{\prime} \mathrm{N}$. The work of Wiseman and Ovey $(1950)$, Bé $(1959,1960)$, Bé and Hamlin (1967), Bradshaw (1959), Parker $(1960,1962)$ and others on the distribution of Recent planktonic Foraminifera has shown that most species are distributed in latitudinal zones. The question arises as to whether similar distribution patterns were in existence during the mid-Tertiary. Planktonic Foraminifera probably had broad patterns of geographic distribution during the midTertiary, however, the latitudinal belts postulated by other workers e. g. (Bandy 1966, Jenkins 1965) were much broader than previously realized.

Fine-grained sediment textures, laminated bedding, plant fragments, and a shelf-depth benthonic fauna all suggest that deposition of Tertiary sediments on the Scotian Slope occurred in a low-energy, outer-shelf environment. Mesozoic and Tertiary sediments collected on the Scotian Shelf represent deposition in the inner neritic zone. The occurrence of a section of these deposits several hundred metres in thickness implies that deposition took place in a subsiding basin. Therefore, there is considerable evidence that a large basin of subsidence may exist along the continental shelf off Nova Scotia. There is also ample indication that the sediments filling this basin are marine in origin and as old as Cretaceous. Furthermore, faunal evidence implies that the sediments underlying the Continental Shelf off Nova Scotia and Newfoundland are a continuation of the Gulf Coast and Atlantic Coastal Plain physiographic province.

\section{Summary}

Planktonic and benthonic foraminiferal assemblages in Scotian Slope mid-Tertiary sediments are comparable to those described from Trinidad, Venezuela and Brazil, in particular, and the Caribbean area in general. The similarity of these assemblages with those in the Caribbean area suggests the presence of a warm-water connection and a warm climatic belt extending from the Caribbean to at least southern Newfoundland (North latitude 46 degrees) during mid-Tertiary time. Paleontological, sedimentological and structural evidence implies that the Continental Shelf off Nova Scotia is a continuation of the Gulf Coast and Atlantic Coastal Plain physiographic province.

\section{References cited}

BANDY, O. L., 1960, Planktonic foraminiferal criteria for paleoclimatic zonation. Tohoku Univ. Sci. Repts., ser. 2 (Geol.), spec. vol., no. 4, pp. 1-8.

, 1964, Cenozoic planktonic foraminiferal zonation. Micropaleontology, vol. 10, no. 1, pp. $1-17$.

1966, Restrictions of the 'Orbulina' datum. Department of Geol. , Univ. of S. Cal., Los Angeles, Cal.

BANNER, F. T., and BLOW, W. H., 1962, Progress in the planktonic foraminiferal biostratigraphy of the Neogene. Nature, vol. 208, no. 5016, pp. 1164-1166.

BARTLET T, G.A., 1967, Planktonic Foraminifera in the Oligocene-Miocene Formations on the Continental Slope off Nova Scotia, World Planktonic Conference, Geneva, Switzerland.

1968, Planktonic Foraminifera - new dimensions with the Scanning Electron

Microscope. Can. Jour. Earth Sci., 5, pp. 231-233, pls. 1-5.

BE, A. W. H. , 1959, Ecology of Recent planktonic Foraminifera; Part I - Areal distribution in the western North Atlantic. Micropal. 5 (1), p. 77-100, pls. 1, 2, test-figs. 1-52, tables 1, 2 .

1960, Some observations on Arctic planktonic Foraminifera. Cushman Found. Foram. Res., Contr., $11(2)$, p. 64-68, text-fig. 1, table 1.

, and HAMLIN, W. H. , 1967, Ecology of Recent planktonic Foraminifera, Part III Distribution in the North Atlantic. During the summer of 1962: Micropaleontology V 13, 
No. 1, pp. $87-106$.

BERGGREN, W.A. , 1963, Some problems of Paleocene stratigraphic correlation. Inst. Franc. Pétrole. Rév., vol. 18, no. 10, pp. 134-143, 2 figs.

BERMUDEZ, P.J., 1949, Tertiary smaller foraminifera of the Dominican Republic. Cushman Lab. Foram. Res., Spec. Publ., no. 25, pp. 1-322, pls. 1-26.

BLOW, W. H., 1956, Origin and evolution of the foraminiferal genus Orbulina d'Orbigny. Micropaleontology, vol. 2, no. 1, pp. 57-70, text-figs. 1-4.

, 1959, Age, correlation, and biostratigraphy of the Upper Tocuyo (San Lorenzo and Pozón Formations, eastern Falcon, Venezuela. Bull. Amer. Pal., vol. 39, no. 178, pp. 59-251, pls. 16-19.

, and BANNER, F. T., 1966, The Morphology, taxonomy and biostratigraphy of Globorotalia barisanensis LeRoy, Globorotalia fohsi Cushman and Ellisor, and related taxa. Micropaleontology, vol. 12, no. 3, pp. 286-302, pls, 1-2.

BOLLI, H. M. , 1957, Planktonic foraminifera from the Oligocene-Miocene Cipero and Lengua Formations of Trinidad, B.W.I. U.S. Nat. Mus., Bull., no. 215, pp. 97-123, pls. 2229, text-figs. 17-21.

, 1967, The subspecies of Globorotalia fohsi Cushman and Ellisor and the zones based on them. Micropaleo, vol. 13, no. 4, pp. 502-512.

BRADSHAW, J.S., 1959, Ecology of living planktonic foraminifera in the North and Equatorial Pacific Ocean. Cushman Found. Foram. Res., Contr., vol. 10, pp. 25-64.

BRONNIMANN, P., 1950, Occurrence and ontogeny of Globigerinatella insueta Cushman and Stainforth from the Oligocene of Trinidad, B. W.I. Contr. Cushman Found. Foram. Res., vol, 1, pts, 3-4, pp. 80-82, pls. 13-14.

1951a, Globigerinita naparimaensis n. gen; n. sp., from the Miocene of Trinidad, B. W. I. Contr. Cushman Found. Foram. Res, , vol. 2, pt. 1, pp. 16-18, textfigs. 1-14.

, 1951b, The genus 'Orbulina' d'Orbigny in the Oligo-Miocene of Trinidad, B.W.I. Contr. Cushman Found. Foram. Res., vol. 2, pt. 4, pp. 132-138, text-figs. 2-5.

CIFELLI, R, , 1962, Some dynamic aspects of the distribution of planktonic Foraminifera in the western North Atlantic, Sears Found. Journ. Marine Res., vol, 20, No. 3, pp. 201-213.

1965, Planktonic Foraminifera from the Western North Atlantic. Smithsonian Misc., Coll., Vol. 148; No. 4.

CLOSS, D. , 1967, Miocene planktonic Foramintfera from Southern Brazil. Micropaleo., v. 13, n. 3, pp. $337-344$.

CUSHMAN, J.A., and CAHILL, E. D., 1933, Miocene Foraminifera of the Coastal Plain of the eastern United States: U.S. Geol. Survey Prof. Paper 175, pp. 1-50,

, and JARVIS, P. W., 1936, Three new Foraminifera from the Miocene Bowden marl of Jamaica. Contr. Cushman Lab. Foram. Res., vol. 12, pt. 1, pp. 3-5, pl. 1.

, and RENZ, H. H. , 1941, New Oligocene-Miocene Foraminifera from Venezuela. Contr. Cushman Lab. Foram. Res, vol. 17, pt. 1, pp. 1-27, pls. 1-4.

, and 1947. The foraminiferal fauna of the Oligocene Ste. Croix formation of Trinidad, B. W. I. Cushman Lab, Foram. Res, Spec. Publ. 22, pp. 1-46, pls. 1-8. 
CUSHMAN, J.A., and STAINFORTH, R. M., 1945, The foraminifera of the Cipero marl formation of Trinidad, British West Indies. Cushman Lab. Foram. Res., Spec. Publ. , no. 14, pp. 1-75, pls. 1-16.

DROOGER, C. W. , 1954, The Oligocene-Miocene boundary on both sides of the Atlantic. Geol. Mag., vol. 91, no. 6, pp. 514-518.

, 1956, Transatlantic correlation of the Oligo-Miocene by means of Foraminifera. Micropaleontol., vol. 2, no. 2, pp. 183-192, pl. 1.

1960, Die biostratigraphischen Grundlagen der Gliederung des marinen Neogensan den Typlokalitaten. Geol. Ges. Wien, Mitt., vol. 52, pp. 105-114, text-fig. 1.

EAMES, F.E., BANNER, F. T., BLOW, W. H., and CLARKE, W. J., 1962, Fundamentals of mid-Tertiary stratigraphical correlation. London: Cambridge University Press, pp. 1163, pls. $1-17$.

FINLAY, H. J., 1947, New Zealand Foraminifera, key species in stratigraphy, no. 5. New Zealand Tour. Sci. Technol., 28 (5), p. 259-292, pls. 1-9.

HEEZEN, B. C. , THARP, M. , and EWING, M., 1959, The floors of the oceans 1 . The North Atlantic. Geol. Soc. Amer., Spec. Paper 65, p. 122.

HOFKER, J., 1954, Morphology of Globigerinatella insueta Cushman and Stainforth. Cushman and Stainforth. Cushman Found. Foram. Res., Contr., vol. 5, pt. 4, pp. 151-157.

1961, On the 'genus' Catapsydrax, and the Globigerina quadrilobata gens. Cushman Found. Foram. Res., Contr., vol. 12, pt. 2, pp. 64-68.

HORNIBROOK, N. deB., 1958, New Zealand Upper Cretaceous and Tertiary foraminiferal zones and some overseas correlations. Micropaleontology, vol. 4, no. 1, pp. 28-35.

JENKINS, D. G. , 1958, Pelagic Foraminifera in the Tertiary of Victoria. Geol. Mag., vol. 95, pp. $438-439$.

1960, Planktonic Foraminifera from the Lakes Entrance oil shaft, Victoria, Australia. Micropaleontology, vol. 6, no. 4, pp. 345-371, pls. 1-5, text-figs. 1-10.

- 1966, Planktonic Foraminifera from the type Aquitainian-Burdigalian of France. New Zealand Geol. Survey, Lower HuH, New Zealand.

KUGLER, H. G., 1954, The Miocene/Oligocene boundary in the Caribbean region. Geol. Mag. , vol. 91, no. 5, pp. $410-414$.

LeROY, L. W. , 1948, The foraminifer Orbulina universa d'Orbigny, a suggested middle Tertiary time indicator. Jour. Pal, , vol. 22, no. 4, pp. 500-508, text-figs. 1-4.

MctAVISH, R. A., 1966, Planktonic Foraminifera from the Malaita Group, British Solomon Islands. Micropaleo., v. 12, n. 1, pp. 1-36.

PARKER, F. L., 1960, Living planktonic Foraminifera from the equatorial and southeast Pacific. Tohoku Univ., Sci. Repts., 2nd. ser. (Geol.), spec. vol. no. 4, pp. 71-82.

1962, Planktonic foraminiferal species in Pacific sediments. Micropal. , 8 (2), p. 219-254, pls. 1-10.

PURI, H. S., 1953, Contribution to the Study of the Miocene of the Florida Panhandle. Florida Geological Survey, Geol. Bull. 36, p. 345 pages.

RENZ, H. H., 1948, Stratigraphy and fauna of the Agua Salada Group, State of Falcon, Venezuela. Geol. Soc. Amer., Mem., no. 32, pp. 1-219, pls. 1-12, text-figs. 1-15. 
SAITO, T., 1963, Miocene planktonic Foraminifera from Honshu, Japan. Tohoku Univ., Sc. Rept., 2nd Series (Geology), v. 35, n. 2, 209 pages.

STAINFORTH, R. M., 1948b, Description, correlation and paleoecology of Tertiary, Cipero marl. formation, Trinidad, B. W. I. Bull. Amer. Assoc. Petr. Geol, vol. 32, no. 7, pp. 12921330,2 text-figs.

WISEMAN, J. D. H., and OVEY, C. D., 1950, Recent investigations on the deep-sea floor. Geol. Assoc., Proc., vol. 61, pt. 1, pp. 28-84, pls. 2-3, text-fig. 1-8.

\section{Faunal Reference List}

Catapsydrax đissimilis (Cushman and Bermudéz) = Globigerina dissimils Cushman and Bermudéz 1937, Contr. Cushman Lab. Foram. Res., vol. 13, pt. 1, p. 25, pl. 3, figs. 4-6.

Catapsydrax stainforthi Bolli, Loeblich \& Tappan, 1957, U. S. Nat. Mus., Bull., vol. 215, p. 37, pl. 7, fig. 11 .

Globigerina ciperoensis angustiumbilicatula Bolli, 1957, U. S. Nat. Mus. Bull., vol. 215, p. 109, pl. 22 , figs. $12 \mathrm{a}-13 \mathrm{c}$.

Globigerina foliata Bolli, 1957, U.S. Nat. Mus. Bull., vol, 215, p. 111, pl. 24, figs. 1a-c.

Globigerina nepenthes Todd, 1957, U. S. Geol. Survey, Prof. Paper No. 280H, p. 301, p1. 78, fig. 7 .

Globigerinita naparimaensis Bronnimann, 1951, Contr. Cushman Found. Foram. Res., vol. 1, pts. $3-4$, p. 82 , p1. 14, fig. 11 .

Globigerinatella insueta Cushman and Stainforth, 1945, Cushman Lab. Foram. Res., Spec. Publ. no. 14, p. 69, pl. 13, figs. 7-9.

Globigerinoides bisphericus Todd, 1954 in Todd, Cloud, Low and Schmidt, Amer. Jour. Sci., vol. 252 , no. 11, p. 681, p1. 1, figs. $1,4$.

Globigerinoides ruber (d'Orbigny) = Globigerina rubra d'Orbigny, 1839, Foraminiferes, in de la Sagra, Hist. Phip. Pol. Nat, Cuba, pp. 82-83, pl. 4, figs. 12-14.

Globigerinoides trilobus altiaperturus Bolli, 1957, U.S. Nat. Mus., Bull., vol. 215, p. 113, p1. 25 , figs. $7-8$.

Globigerinoides trilobus immaturus LeRoy = Globigerinoides sacculiferus (Brady) var. immatura LeRoy, 1939, Natuurk. T. jdschr, Neder1. - Indie, Batavia, vol. 99, pt. 6, p. 263 , pl. 3, figs. 19-21.

Globigerinoides trilobus trilobus (Reuss) $=$ Globigerina triloba Reuss, 1850, K. Akad. Wiss. Wien, Math. - Nat. C1., Denkschr., vol, 1, p. 374, pl. 47, fig. 11.

Globorotalia archeomenardii Bolli, 1957, U.S. Nat. Mus., Bull., vol. 215, p. 119, pl. 28, figs. lla-c.

Globorotalia fohsi fohsi Cushman and Ellisor, 1939, Cushman Lab. Foram. Res. Contr., vol. 15 , pt. 1, p. 12, pl. 2, fig. 6 .

Globorotalia fohsi peripheroronda (Blow and Banner) = Turborotalia peripheroranda Blow \& Banner, 1966, Micropaleontology, vol. 12, no. 3, p. 294, pl. 1, figs. la-c, pl. 2, figs. 13.

Globorotalia fohsi praefohsi (Blow and Banner) = Globorotalia praefohsi Blow and Banner 1966 , Micropaleontology, vol. 12, no. 3, p. 295, p1. 1, figs. 3-4, pl. 2, figs. 6-7, 10-11,

Globorotalia fohsi robusta Bolli, 1950, Cushman Found. Foram. Res., Contr., vol. 1, pts. 3-4, pp. 84,89, pl. 15, fig. 3.

Globorotalia kugleri Bolli, 1957, U. S. Nat. Mus., Bull., vol. 215, p. 118, pl. 28, figs. 5-6.

Globorotalia mayeri Cushman and Ellisor, 1939, Cushman Lab. Foram. Res. , Contr., vol. 15, pt. 1, p. 11, pl. 2, fig. 4.

Globorotalia menardii menardii (d'Orbigny) = Rotalia menardii d'Orbigny, 1826, Ann. Sci. Nat., ser. 1, vol. 7, p. 273; Modéles, no. 10 .

Globorotalia menardii miotumida Jenkins, 1960, Micropaleontology, vol. 6, no. 4, p. 362, pl. 4, figs! $9 a-c$.

Globorotalia menardii praemenardii Cushman and Stainforth = Globorotalia praemenardii Cushman and Stainforth, 1945, Cushman Lab. Foram. Res., Spec. Publ. no. 14, p. 70, p1. 13, fig. 14.

Globorotalia opima opima Bolli, 1957, U.S. Nat. Mus., Bull., vol. 215, p. 117, pl. 28, figs. la-2. Globoquadrina dehiscens dehiscens (Chapman, Parr and Collins) = Globorotalia dehiscens Chapman, Parr and Collins 1934, Linnean Soc. London, Jour., Zool., vol. 38, no. 252, p. 569 , p1. 11, fig. 36 .

Globoquadrina venezuelana (Hedberg) = Globigerina venezuela Hedberg, 1937, Jour. Paleontol., vol. 11, no. 8, p. 681 , pl. 92 , figs. $7 a, b$.

Porticulasphaera glomerosa glomerosa $(B l o w)=$ Globigerinoides glomerosa glomerosa Blow, 1956, Micropaleontology, vol. 2, no. 1, p. 65, text-fig. 1, nos. 15-19, text-fig. 2 , nos. $1-2$. 